\title{
Nutritional Assessment of Children with Acute Lymphoblastic Leukemia
}

\author{
Rula Ahmed Abdul Kadir, Janan G Hassan and Mohammed K Aldorky
}

Department of Pediatrics, College of Medicine, University of Basra, Iraq

Corresponding author: Janan G Hassan, Department of Pediatrics, College of Medicine, University of Basra, Iraq, Tel: 9647801000820; E-mail: jenan_ah03@yahoo.com

Received: 25 May 2016; Accepted: 27 January 2017; Published: 31 January 2017

Citation: Kadir RAA, Hassan JG, Aldorky MK. Nutritional Assessment of Children with Acute Lymphoblastic Leukemia. Arch Can Res. $2017,5: 1$.

\section{Abstract}

Background: The high prevalence of malnutrition in adult and pediatric cancer patients has been appreciated for decades and continues to be documented. Although the prognostic significance of nutritional status among patients with cancer remains controversial, it is generally accepted that the nutritional support is an important aspect of medical therapy.

Objective: Assess the nutritional status of children with acute lymphoblastic leukemia at time of diagnosis of disease, assess the nutritional status of the same children during induction of chemotherapy and after induction by 3-6 weeks.

Patients and methods: A prospective study was carried out on thirty children their age ranged from (1-14 year) with newly diagnosed acute lymphoblastic leukemia, (16) of them were males and (14) were females, who were admitted to the oncology pediatric Unit in Basrah Maternity and children Hospital, from the first of January to the end of October -2010). This study has been done to determine the nutritional status of children with newly diagnosed acute lymphoblastic leukemia before, during and after induction by (3-6 weeks). Full history was taken from each patient regarding chief compliant, dietary history, also clinical examination and anthropometric measurement by measure weight, height, mid upper arm circumference and body mass index, in addition investigation in form of $\mathrm{Hb}$, serum albumin, serum cholesterol, and random blood sugar.

Results: This study has revealed that among 30 patients with newly diagnosed ALL, 15 (50\%) of them are underweight according to weight for age, 8 of them are male and 7 are females. Twelve (40\%) of these 30 patients are wasted, 7 of them are male and 5 are female. Fourteen $(46.7 \%)$ of the total 30 patients are malnourished according to body mass index, 6 of them are male and 8 are female, ten (33.3\%) are malnourished according to mid upper arm circumference, five of them are male and 5 are female. The study has revealed that there is a statistically significant increase in mean body weight during induction with $P$ value $(0.046)$ and a statistically increase in body mass index during induction with $P$ value $(0.005)$. During induction, there is decrease in serum calcium with $P$ value $(0.001)$, and a significant decrease in serum albumin with $P$ value $(0.005)$, also in this study there is a significant decrease in serum cholesterol during induction with $P$ value $(0.001)$. There is no significant increase in random blood sugar during induction.

Conclusion: Malnutrition exists in a significant proportion of children with acute lymphoblastic leukemia. So, adequate nutrition is an important in such children, to ensure optimal treatment and outcome.

Keywords: Lymphoblastic Leukemia; malnutrition; Pediatric cancer

\section{Introduction}

The high prevalence of malnutrition in adult and pediatric cancer patients has been appreciated for decades and continues to be documented. Although the prognostic significance of nutritional status among patients with cancer remains controversial, it is generally accepted that the nutritional support is an important aspect of medical therapy. Parents of children with cancer are often quite concerned about issues of appetite and other gastrointestinal symptoms even when death is imminent [1]. The incidence of malnutrition at the time of diagnosis of cancer in children appears to be less than adult. Some children were malnourished at the time of diagnosis and their malnourishment was reported to have increased during the therapy for malignancy, especially if their treatment involved intensive chemotherapy or bone marrow transplantation.

Children treated for leukemia underwent changes in nutritional status, as manifested by a reduction in growth, weight gain and weight losses. A child with newly diagnosed cancer appears to have the same average nutritional status as seen in the population from which the child come, if the diagnosis is made in a reasonably timely manner [2].

In the last decade, improved chemotherapy strategies for children with leukemia have resulted in a dramatic improvement in the survival rates. Malnutrition more often develops during intensive induction therapy but it less commonly apparent at diagnosis [3]. 
The occurrence of wasting among cancer patients is determined by host susceptibility, tumor type and location, and anticancer regimen. The rational for identifying, treating, and preventing malnutrition among pediatric cancer patients may be summarized as follows: Malnutrition is common among patients with cancer both on presentation and with subsequent antitumor therapy, weight loss, deficits in weight for height (wasting), and deficits in height for age (stunting) are observed [1]. There are no known disease processes where malnutrition is advantageous to the host. There is an increased morbidity from malnutrition in hospitalized patients, including delayed wound healing, increased infectious complications, decreased immune competence, reduced respiratory and other muscle strength, and increased length of stay. The nutrition literature in pediatrics confirm wasting as an important risk factor for early death, Moreover, acute malnutrition is marked by depression and apathy, and chronic malnutrition by delayed neurodevelopment. All the morbidities named above are common in pediatric cancer patients [1]. Malnutrition in pediatric cancer patients has been associated Within tolerance to chemotherapy [1].

Early recognition of patients at risk for malnutrition can obviate the need for more aggressive supports subsequently in the patients course [1].

Insufficient energy and nutrients intake (due to anorexia, taste changes, pain, nausea; adverse effect of cancer therapy, psychological problems), Pathologic alterations in nutrient metabolism (e.g. increase protein turnover, decrease muscle protein synthesis, increase lipolysis, increase fatty acid oxidation, increase hepatic glucose production, increase hepatic protein synthesis, increase acute phase proteins) [4], the side effects of the cancer treatment can also affect dietary input by triggering nausea, vomiting and mucositis, ALL patients take steroids during their treatment, this can cause an increase appetite and weight gain. This has been linked to the escalation of obesity in pediatric ALL survivors, which is four to five times more likely than expected, Leukemia and lymphoma patients can have an enlarged spleen, this effect on the patient's stomach thus reducing their appetite [5]. Nutrition is a supportive care modality that has associated with improved tolerance to chemotherapy, improved survival, increased quality of life, and decreased risk of infection in children undergoing anticancer therapy [6]. The goal of nutritional assessment in childhood is to prevent nutritional disorders and the increased morbidity and mortality that accompany them. Nutritional assessment is the quantitative evaluation of nutritional status. A comprehensive nutritional assessment has five components:

1. Growth, anthropometric and body composition measurements.

2. Physical examination.

3. Growth, anthropometric and body composition measurements.

4. Laboratory tests.

5. Intervention and monitoring [7].
Children from developing countries are at risk for primary malnutrition. Children undergoing anticancer therapy are at higher risk for secondary malnutrition, including obesity and growth retardation. Objective and subjective data should be used to complete the nutritional assessment. Different parts of nutritional assessment include medical history; physical examination; biochemical and hematological data, anthropometric measurements and food and nutrition history. Malnutrition can lead to a decreased immune function, in already immune compromised patients; delay wound healing and reduce drug metabolism. Also, as mentioned earlier it can be a contributing factor to death and poor prognosis $[1,8,9]$.

Biochemical data: Serum proteins serum albumin became the gold standard for indicating nutritional status in patients.

Blood glucose levels: Malnutrition can cause glucose intolerance and impairment of insulin secretion

Lipid profile: A diet high in saturated fats and transfers can increase total cholesterol levels. Plant based diets high in fiber and unsaturated fatty acids can lower total cholesterol. Hemoglobin/Hematocrit in state of malnutrition, hemoglobin and hematocrit tend to decrease because of inadequate amount of protein consumption and possibly iron deficiency [9].

Aims of the study: This prospective study was carried out to assess the nutritional status of children with acute lymphoblastic leukemia at time of diagnosis of disease, assess the nutritional status of the same children during induction of chemotherapy and after induction by 3-6 weeks.

\section{Patients and Methods}

\section{Patients}

A prospective study has been carried out on children and adolescents with newly diagnosed acute lymphoblastic leukemia over ten months (from the first of January till the end of October -2010).

The data was collected from oncology pediatric ward in Basrah Maternity and Children Hospital. A total of 30 newly diagnosed ALL patients, their ages range from 1-14 years were included in this study.

\section{Data collection}

A special questionnaire was designed for the study. The following information were taken: name, age, sex, date of admission, diagnosis, and residence.

\section{ALL classification according to:}

1. Risk group (Standard Risk and High Risk)

2. Morphology (L1, L2, L3).

High risk ALL: Age at presentation less than 1 year and more than 10, Sex: male, W.B.C $>50,000 / \mathrm{mm}^{3}$ at diagnosis, C.N.S manifestation at time of presentation, Platelet count 
$<50,000 / \mathrm{mm}^{3}$ at time of presentation Immunophenotyping: pro B ALL cell type.

\section{Morphological subtypes}

Acute lymphoblastic leukemia divided into 3 groups according to FAB classification: L1, L2, L3. This classification depends on size of nucleus, amount of cytoplasm, cytoplasm basophilic and nuclear cytoplasm ratio [1].

L1 comprises $85 \%$ of ALL in childhood while L2 comprises $14 \%$, and L3 comprises $1 \%$, the L1 morphology has been associated with higher remission rate and a better event free survival (EFS) than L2 morphology which appears to convey poor prognosis and patient with $L 3$ have the worst over all prognoses [10].

\section{Clinical data}

Pallor, bleeding, fever, wasting, edema, abdominal distension, irritability or apathy, bone or joint pain, hair changes, lymph node enlargement, vomiting, skin lesion due to infection or vitamin deficiency such as vitamin $A$ and $D$, constipation or diarrhea.

Full examination was done to all patients including general and systemic examination. An informed consent was obtained from one or both parents, for recruitment in the study.

\section{Methods}

\section{Anthropometric measurement}

The basic anthropometric measurements for which reference data exist for comparison are weight, stature (length or height), mid arm circumference.

Weight: Weight loss is a good indicator of acute nutritional insult in children, reflecting loss of fat, muscle, other soft tissue, and water taken to the nearest $0.1 \mathrm{Kg}$. Electronic scale SEGA was used to measure weight of children wearing minimum clothing.

Height or length: Height or length generally correlates better with socioeconomic status than soft tissue measurement such as weight. Length is usually indicated for children up to 24 months of age, and height is used thereafter. Height of the children were measured by using SEGA Stadiometer. The reading was taken to the nearest $0.1 \mathrm{~cm}$.

\section{Mid-upper arm circumference}

An advantage of the MUAC is that there is very little change between ages 1 and 4 years. MUAC measurement done by using tape measure.

\section{Body mass index}

Body mass index (BMI) calculated by using norm gram based on $\{$ Weight $(\mathrm{Kg}) /$ Height $(\mathrm{m}) 2\}$. BMI assess adiposity status.
The anthropometric indices were calculated by using reference median as recommended by the National Centre for Health Statistics (NCHS) (WHO) and classified according to standard deviation units termed as Z score based on World Health Organization (WHO) criterion. Children who were less than 2 standard deviations below the reference median (-2SD) were considered as under-weight (weight for age), and wasted.

\section{Hematological and biochemical data}

Four milliliters of venous blood were withdrawn from each patient. One milliliter was put in (EDTA) containing tube and send for $\mathrm{Hb} \%$.

The remaining 3 milliliters of blood were put in plain tube without EDTA, centrifuged and send for: Random blood sugar (RBS), total serum protein and serum albumin, Serum calcium and Serum Cholesterol.

\section{Statistical analysis}

Statistical analysis was done using SPSS program [11], data were expressed by means \pm Standard Deviation. Comparisons of proportions was performed by crosstab using Chi-Square test. The t-test used for quantitative comparisons of anthropometric measurement, hematological and biochemical variables before, during and after induction of chemotherapy.

For all tests, $\mathrm{P}$ value of $<0.05$ was considered as statistically significant.

\section{Results}

Table 1 reveals A total of 30 children with newly diagnosed ALL were included in this study, their age range from (1-14) years, mean age $(5.4 \pm 3.4 \mathrm{SD})$. Sixteen were males and fourteen were females, reveals that 16 (53.3\%) of patients included in this study were males and 14 (46.6\%) were females. More than (60\%) of patients lies in the age group (1$<5)$ for both males and females.

Table 1 Age and sex distribution of patients with Acute lymphoblastic Leukemia.

\begin{tabular}{|c|c|c|c|c|c|c|}
\hline \multirow[t]{3}{*}{ Age } & \multicolumn{6}{|c|}{ Sex } \\
\hline & \multicolumn{2}{|c|}{ Male } & \multicolumn{2}{|c|}{ Female } & \multicolumn{2}{|c|}{ Total } \\
\hline & No & $\%$ & No & $\%$ & No & $\%$ \\
\hline $1-<5$ & 10 & $62.5 \%$ & 7 & $50 \%$ & 17 & $56.6 \%$ \\
\hline $\begin{array}{l}5 \\
<10\end{array}$ & 3 & $18.75 \%$ & 4 & $28.58 \%$ & 7 & $23.3 \%$ \\
\hline $10-14$ & 3 & $18.75 \%$ & 3 & $21.42 \%$ & 6 & $20 \%$ \\
\hline Total & 16 & $100 \%$ & 14 & $100 \%$ & 30 & $100 \%$ \\
\hline
\end{tabular}

Table 2 shows past feeding history in early life include breast, bottle and mixed feeding (breast and bottle feeding) shows that nineteen patients with newly diagnosed ALL with 
breast feeding and ordinary diet. Seven patients with mixed feeding and ordinary diet.

Table 2 Distribution of patients according to the type of feeding.

\begin{tabular}{|l|l|l|}
\hline Type of feeding & Frequency & $\%$ \\
\hline Breastfeeding and ordinary diet & 19 & $63.3 \%$ \\
\hline Bottle feeding and ordinary diet & 4 & $13.3 \%$ \\
\hline Mixed feeding and ordinary diet & 7 & $23.3 \%$ \\
\hline
\end{tabular}

Table 3 shows the two main risk groups of ALL are standard risk and high risk, according to morphology ALL subdivided into L1, L2 and L3. Two third of patients according to risk group are with high risk, according to morphology twenty five out of thirty newly diagnosed ALL with L2.

Table 3 ALL Classification according to risk group and morphology.

\begin{tabular}{|l|l|l|l|}
\hline \multirow{2}{*}{ ALL Risk No.30 } & \multicolumn{2}{|c|}{ Standard Risk (\%) } & High Risk (\%) \\
\cline { 2 - 4 } & \multicolumn{2}{|c|}{$\mathbf{9 ( 3 0 \% )}$} & $\mathbf{2 1}(\mathbf{7 0} \%)$ \\
\hline \multirow{2}{*}{$\begin{array}{l}\text { ALL Morphology No. } \\
30\end{array}$} & L1 (\%) & L2 (\%) & L3 (\%) \\
\cline { 2 - 4 } & $3(10 \%)$ & $25(83.3 \%)$ & $2(6.6 \%)$ \\
\hline
\end{tabular}

Table 4 shows nutritional indices of children with ALL were studied and present that half of the patients are underweight at presentation and one third of the thirty newly diagnosed patients are malnourished according to mid upper arm circumference.

Tables 3-5 show thirty patients with newly diagnosed ALL underwent somatometric measurement at initial presentation, during induction with chemotherapy and after induction. that the body weight increase during induction of chemotherapy than before induction and statistically significant with $P$ value of 0.045 . Body mass index was increase during induction and statistically significant with $P$ value of 0.005 . There is no difference in MUAC in both groups and it is statistically not significant, $P$ value of 0.083 . There is no change in growth parameters during and after induction of chemotherapy by six weeks.

Table 4 Indices of malnutrition at presentation.

\begin{tabular}{|c|c|c|c|c|}
\hline \multirow[t]{2}{*}{ Indices } & \multicolumn{2}{|c|}{ At presentation } & \multicolumn{2}{|l|}{ Sex } \\
\hline & No. & $\%$ & Male & Female \\
\hline Under nutrition & 15 & $50 \%$ & 8 & 7 \\
\hline Wasting & 12 & $40 \%$ & 7 & 5 \\
\hline $\mathrm{BMI}<5^{\text {th }}$ centile & 14 & $46.7 \%$ & 6 & 8 \\
\hline MUAC $<5^{\text {th }}$ centile & 10 & $33.3 \%$ & 5 & 5 \\
\hline
\end{tabular}

Table 6 shows hemoglobin, total serum protein, serum albumin, serum calcium, serum cholesterol and blood sugar were assessed for all patients included in the study before, during and after induction and the result are that the $\mathrm{Hb}$ level was significantly higher during induction than before induction with $P$ value of 0.000 , also show that the serum calcium level was decrease during induction with significant $P$ value of 0.001 . Serum protein and albumin decrease during induction with significant $P$ value of 0.000 and 0.005 respectively. Serum cholesterol was decrease during induction with significant $P$ value of 0.001 . There was no statistical significant difference between blood sugar before and during induction with $P$ value of (0.771). There was no statistical significant difference between all the above indices during and after induction.

Table 5 Growth parameters before, during and after induction.

\begin{tabular}{|c|c|c|c|c|c|c|}
\hline Indices No. 30 & Before* induction & During* induction & $P$ value & During* induction & After* induction & P Value \\
\hline Weight & $\begin{array}{l}18.806 \pm \\
9.7107\end{array}$ & $\begin{array}{l}19.4567 \pm \\
9.3958\end{array}$ & 0.046 & $\begin{array}{l}19.4567 \pm \\
9.3958\end{array}$ & $\begin{array}{l}18.9967 \pm \\
9.3958\end{array}$ & 0.141 \\
\hline Height & $\begin{array}{l}107.9 \pm \\
21.7721\end{array}$ & $\begin{array}{l}107.9 \pm \\
21.7721\end{array}$ & 1.000 & $\begin{array}{l}107.9 \pm \\
21.7721\end{array}$ & $\begin{array}{l}107.9 \pm \\
21.7721\end{array}$ & 1.000 \\
\hline Mid arm circumference & $\begin{array}{l}15.26 \pm \\
2.6400\end{array}$ & $\begin{array}{l}15.5966 \pm \\
2.8229\end{array}$ & 0.083 & $\begin{array}{l}15.5966 \pm \\
2.8229\end{array}$ & $\begin{array}{l}15.0083 \pm \\
3.50473\end{array}$ & 0.357 \\
\hline Body mass index & $\begin{array}{l}15.37 \pm \\
2.1115\end{array}$ & $\begin{array}{l}16.07 \pm \\
2.0983\end{array}$ & 0.005 & $\begin{array}{l}16.07 \pm \\
2.0983\end{array}$ & $\begin{array}{l}15.7323 \pm \\
2.0983\end{array}$ & 0.056 \\
\hline
\end{tabular}

Table 7 shows sixteen males from the total number (30) patients and fourteen female were assessed for body measurement before and during induction and the result was no significant relation between sex and body weight and body mass index before and during induction of chemotherapy. 
Table 8 shows $\mathrm{Hb}$ and same biochemical investigations (serum protein, serum cholesterol, serum calcium) were studied in relation to sex before and during induction that there is no significant relation between sex and hematological and biochemical data before and during induction.

Table 6 Hematological and biochemical data before, during and after induction.

\begin{tabular}{|c|c|c|c|c|c|c|}
\hline $\begin{array}{l}\text { Indices } \\
\text { No.30 }\end{array}$ & $\begin{array}{l}\text { Before } \\
\text { Induction* }\end{array}$ & During induction* & $P$ value & During induction* & After induction* & $P$ value \\
\hline $\mathrm{Hb}$ & $\begin{array}{l}6.5033 \pm \\
1.9031\end{array}$ & $\begin{array}{l}9.3000 \pm \\
0.6988\end{array}$ & .000 & $\begin{array}{l}9.3000 \pm \\
0.6988\end{array}$ & $12.1100 \pm 15.2856$ & 0.324 \\
\hline Serum calcium & $\begin{array}{l}2.2600 \pm \\
0.2621\end{array}$ & $\begin{array}{l}2.0300 \pm \\
0.3282\end{array}$ & .001 & $\begin{array}{l}2.0300 \pm \\
0.3282\end{array}$ & $2.1267 \pm 0.1701$ & 0.102 \\
\hline Serum protein & $6.7767 \pm 0.9104$ & $\begin{array}{l}5.8167 \pm \\
0.7724\end{array}$ & .000 & $\begin{array}{l}5.8167 \pm \\
0.7724\end{array}$ & $6.0033 \pm 0.8202$ & 0.06 \\
\hline Serum albumin & $4.04 \pm 0.91$ & $3.55 \pm 0.49$ & 0.005 & $3.55 \pm 0.49$ & $3.68 \pm 0.43$ & 0.07 \\
\hline $\begin{array}{l}\text { Serum } \\
\text { cholesterol }\end{array}$ & $\begin{array}{l}172.5333 \pm \\
35.2378\end{array}$ & $\begin{array}{l}144.9333 \pm \\
30.1741\end{array}$ & .001 & $\begin{array}{l}144.9333 \pm \\
30.1741\end{array}$ & $147.6667 \pm 30.343$ & 0.705 \\
\hline R.B.S & $\begin{array}{l}4.9867 \pm \\
0.9402\end{array}$ & $\begin{array}{l}5.8700 \pm \\
1.174\end{array}$ & 0.077 & $\begin{array}{l}5.8700 \pm \\
1.174\end{array}$ & $4.7700 \pm 0.9025$ & 0.201 \\
\hline
\end{tabular}

Table 7 Body measurement and sex before and during induction.

\begin{tabular}{|l|l|l|l|l|}
\hline Indices & \multicolumn{2}{|l|}{ Before induction* } & \multicolumn{2}{l|}{ During induction* } \\
\hline & Male (16) & Female (14) & Male (16) & Female (14) \\
\hline Body weight & $19.7313 \pm$ & $17.7500 \pm$ & $20.1438 \pm$ & $18.6714 \pm$ \\
& 10.6378 & 8.8050 & 9.7992 & 9.2136 \\
\hline Body mass index & $15.6925 \pm$ & $15.0086 \pm 0.05$ & $16.3512 \pm$ & $2.7571 \pm$ \\
& 1.9256 & 2.3235 & 2.1856 & NS $>0.05$ \\
\hline
\end{tabular}

Table 8 Hematological and biochemical data in relation to sex before and during induction.

\begin{tabular}{|c|c|c|c|c|c|}
\hline \multirow[t]{2}{*}{ Indices } & \multicolumn{2}{|c|}{ "Before induction } & \multicolumn{2}{|c|}{ "During induction } & \multirow[t]{2}{*}{$P$ value } \\
\hline & Male (16) & Female (14) & Male (16) & Female (14) & \\
\hline $\mathrm{Hb}$ & $6.7813 \pm 2.1037$ & $6.1857 \pm 1.6640$ & $9.3188 \pm 0.8224$ & $9.2786 \pm 0.5549$ & NS $>0.05$ \\
\hline Serum protein & $6.7813 \pm 0.6685$ & $6.7714 \pm 1.1545$ & $5.8687 \pm 0.8700$ & $5.7571 \pm 0.6711$ & NS $>0.05$ \\
\hline Serum Calcium & $2.2875 \pm 0.2754$ & $2.2286 \pm 0.2525$ & $2.0250 \pm 0.3435$ & $2.0357 \pm 0.3225$ & NS $>0.05$ \\
\hline $\begin{array}{l}\text { Serum } \\
\text { Cholesterol }\end{array}$ & $\begin{array}{l}170.8750 \pm \\
33.5477\end{array}$ & $\begin{array}{l}174.4286 \pm \\
38.2637\end{array}$ & $\begin{array}{l}142.3750 \pm \\
27.5097\end{array}$ & $\begin{array}{l}147.8571 \pm \\
33.7727\end{array}$ & NS $>0.05$ \\
\hline
\end{tabular}

Table 9 shows nine patients with standard risk ALL and 21with high risk ALL their body weight and body mass index were evaluated before and during therapy no significant relation between body measurement and ALL risk group before and during therapy.
Table 10 shows no significant relation between risk group and hematological and biochemical data before and during induction.

Table 11 shows twenty-five patients belong to L2 subtype, 3 were L1 subtype, their weight and body mass index were evaluated before and during induction in relation to 
morphological subtypes and the result was shown no significant relation between morphological subtypes and body measurement before and during induction.

Table 9 Body measurement and risk group before and during induction.

\begin{tabular}{|l|l|l|c|c|}
\hline \multicolumn{2}{|l|}{ ALL Risk Group. NO. } & Bodyweight* & P value & Body mass index* \\
\hline $\begin{array}{l}\text { Before } \\
\text { Therapy }\end{array}$ & Standard Risk (9) & $15.6889 \pm 3.0937$ & 0.249 & $14.2900 \pm 1.7384$ \\
\cline { 2 - 4 } & High Risk (21) & $20.1429 \pm 11.2540$ & $15.8376 \pm 2.1216$ \\
\hline $\begin{array}{l}\text { During } \\
\text { Therapy }\end{array}$ & Standard Risk (9) & $17.0778 \pm 3.5113$ & 0.371 & $15.5743 \pm 2.1247$ \\
\cline { 2 - 4 } & High Risk (21) & $20.4762 \pm 10.9287$ & & $16.2881 \pm 2.1019$ \\
\hline
\end{tabular}

Table 10 Hematological and biochemical data in relation to risk group before and during induction.

\begin{tabular}{|c|c|c|c|c|c|c|c|c|c|}
\hline \multicolumn{2}{|l|}{ ALL Risk } & \multirow{2}{*}{$\begin{array}{ll}{ }^{*} \mathrm{Hb} \\
\\
6.9556 \quad \pm \\
2.4790\end{array}$} & \multirow{3}{*}{\begin{tabular}{|l} 
P value \\
0.425
\end{tabular}} & $\begin{array}{l}\text { Serum } \\
\text { Protein }\end{array}$ & \multirow{3}{*}{$\begin{array}{l}\text { P value } \\
0.382\end{array}$} & $\begin{array}{l}\text { "Serum } \\
\text { Calcium }\end{array}$ & \multirow{3}{*}{$\begin{array}{l}\text { P value } \\
0.018\end{array}$} & $\begin{array}{l}\text { *Serum } \\
\text { Cholesterol }\end{array}$ & \multirow{3}{*}{$\begin{array}{l}\text { P value } \\
0.98\end{array}$} \\
\hline \multirow[t]{2}{*}{$\begin{array}{l}\text { Before } \\
\text { Therapy }\end{array}$} & $\begin{array}{l}\text { Standard Risk } \\
\text { (9) }\end{array}$ & & & $\begin{array}{ll}6.5222 & \pm \\
0.7918 & \end{array}$ & & $\begin{array}{l}2.1444 \\
0.2128\end{array}$ & & $\begin{array}{l}175.3333 \\
33.0038\end{array}$ & \\
\hline & High Risk (21) & $\begin{array}{l}6.3095 \\
1.6315\end{array}$ & & $\begin{array}{l}6.8875 \\
0.9536\end{array}$ & & $\begin{array}{l}2.3095 \quad \pm \\
0.2700\end{array}$ & & $\begin{array}{l}171.3333 \\
36.8746\end{array}$ & \\
\hline \multirow[t]{2}{*}{$\begin{array}{l}\text { During } \\
\text { Therapy }\end{array}$} & $\begin{array}{l}\text { Standard Risk } \\
(9)\end{array}$ & $\begin{array}{ll}9.0778 & \pm \\
0.3528 & \end{array}$ & \multirow[t]{2}{*}{0.354} & $\begin{array}{l}5.4556 \\
0.8819\end{array}$ & \multirow[t]{2}{*}{0.068} & $\begin{array}{l}2.0778 \quad \pm \\
0.2333\end{array}$ & \multirow[t]{2}{*}{0.528} & $\begin{array}{l}131.6667 \\
23.8965\end{array}$ & \multirow[t]{2}{*}{0.125} \\
\hline & High Risk (21) & $\begin{array}{l}9.3952 \pm \\
0.7915\end{array}$ & & $\begin{array}{l}5.9714 \pm \\
0.6857\end{array}$ & & $\begin{array}{l}2.0095 \pm \\
0.3646\end{array}$ & & $\begin{array}{l}150.6190 \pm \\
31.2833\end{array}$ & \\
\hline
\end{tabular}

Table 11 Body measurement in relation to morphological subtypes before and during induction.

\begin{tabular}{|l|l|c|c|c|c|}
\hline \multicolumn{2}{|l|}{$\begin{array}{l}\text { ALL } \\
\text { Morphological Type }\end{array}$} & No & Body Weight* & P value & Body Mass Index* \\
\hline \multirow{2}{*}{ Before Therapy } & L1 & 3 & $10.6 \pm 1.5$ & 0.143 & $13.4 \pm 0.11$ \\
\cline { 2 - 5 } & L2 & 25 & $19.6 \pm 10.0$ & & $15.5 \pm 2.17$ \\
\hline During Therapy & L1 & 3 & $11.8 \pm 2.4$ & 0.144 & $14.8 \pm 1.2$ \\
\cline { 2 - 5 } & L2 & 25 & $20.4 \pm 9.8$ & & $16.4 \pm 2.0$ \\
\hline *Values were expressed as mean \pm SD
\end{tabular}

Table 12 shows hematological and biochemical data of patients with subgroups L1 and L2 were studied before and during induction and the result revealed no significant relation between morphological subtype and hematological and biochemical data before and during chemotherapy.

\section{Discussion}

Nutritional assessment is the first step of nutritional support which will not improve the child's sense of well-being but also maintain normal growth, promote wound healing, improve tumor response to therapy and enable the child to better withstand the effects of therapy. Assessment will also help prevent over nutrition which may in some instances be detrimental to the treatment of cancer [12-14].

Children with cancer represent a high-risk group for protein energy malnutrition due to side effect associated with treatment, mild to moderate malnutrition is common in leukemia patients at diagnosis and relapse [15].

This prospective study was carried out on thirty patients with newly diagnosed ALL. Of these thirty patients 15 (50\%) are underweight at presentation, while twelve (40\%) are wasted at presentation. In this study 14 (46.7\%) of the total 30 newly diagnosed ALL are malnourished according to BMI $\left(B M I<5^{\text {th }}\right.$ centile), ten (33.3\%) are malnourished according to MUAC (MUAC $<5^{\text {th }}$ centile). A similar survey in India by Rajesh 
et al. was carried out on study group comprised 25 children with newly diagnosed ALL, their age range from (1-12) year, eighteen of them are male and seven are females [16]. In this Indian study show that there is $13(52 \%)$ patients out of these 25 newly diagnosed ALL were underweight at presentation, twelve patients (48\%) were wasted. Nine (36\%) of them were malnourished according to MUAC [16]. Our study is comparable Rajesh et al. study [17]. Sgarberie et al., showed that $30 \%$ of affected children with ALL were wasted on admission [2], while survey from Mexico by Delbecque et al. shown that $21.2 \%$ of ALL patients evaluated had evidence of malnutrition, relatively less than Rajesh et al. and less than this study, which is explained by Delbecque -Boussard et al., as there is low intake of energy, carbohydrate, and protein in case of ALL at time of diagnosis [18]. In the study by Tamminga et al. observed that at the time of diagnosis, $\mathrm{Wt}, \mathrm{Ht}$, wt for ht and mid arm circumference were normal in all patients with ALL in their study [19].

Table 12 Hematological and biochemical data in relation to morphological subtypes before and during induction.

\begin{tabular}{|c|c|c|c|c|c|c|c|c|c|}
\hline \multicolumn{2}{|c|}{$\begin{array}{l}\text { ALL Morphological } \\
\text { subtype No. }\end{array}$} & \multirow{2}{*}{$\begin{array}{l}{ }^{*} \mathrm{Hb} \\
6.10 \pm 1.93\end{array}$} & \multirow{3}{*}{$\begin{array}{l}\text { P value } \\
0.707\end{array}$} & \multirow{2}{*}{$\begin{array}{l}\begin{array}{l}\text { *Serum } \\
\text { Protein }\end{array} \\
7.50 \pm 0.51\end{array}$} & \multirow{3}{*}{$\begin{array}{l}\text { P value } \\
0.085\end{array}$} & \multirow{2}{*}{$\begin{array}{l}\begin{array}{l}\text { *Serum } \\
\text { Calcium }\end{array} \\
2.23 \pm 0.25\end{array}$} & \multirow{3}{*}{$\begin{array}{l}\text { P value } \\
0.857\end{array}$} & \multirow{2}{*}{$\begin{array}{l}\begin{array}{l}\text { *Serum } \\
\text { Cholesterol }\end{array} \\
192.6 \pm 31.0\end{array}$} & \multirow{2}{*}{$\begin{array}{l}\text { P value } \\
0.335 \\
\end{array}$} \\
\hline Before & L1 (3) & & & & & & & & \\
\hline & L2 (25) & $6.55 \pm 1.96$ & & $6.63 \pm 0.69$ & & $2.26 \pm 0.27$ & & $170.8 \pm 36.6$ & \\
\hline \multirow{2}{*}{$\begin{array}{l}\text { During } \\
\text { Therapy }\end{array}$} & L1 (3) & $9.26 \pm 0.46$ & \multirow[t]{2}{*}{0.941} & $6.33 \pm 1.41$ & \multirow[t]{2}{*}{0.274} & $2.5 \pm 0.45$ & \multirow[t]{2}{*}{0.08} & $168.6 \pm 17.2$ & \multirow[t]{2}{*}{0.184} \\
\hline & L2 (25) & $9.30 \pm 0.79$ & & $5.80 \pm 0.69$ & & $2.1 \pm 0.26$ & & $143.4 \pm 31.0$ & \\
\hline
\end{tabular}

In this study changes in body parameters before and during induction show that there is overall increase in body weight during induction (mean increasing $0.6 \mathrm{~kg}$ ), while Rajesh et al. show that there is overall increase in body weight of $(0.3 \mathrm{~kg})$ with a $P$ value of (0.05) [17].

There was a great effect of prednisolone during the weeks of induction by increase food intake, which related to relieve of symptoms and euphoria, over caring for children during illness period and over introduction of best food by the parents [16].

Corticosteroid therapy causes alteration in fat metabolism, which had a net effect of increase body fat and redistribution of body fat causing truncal obesity [16].

In the current study one patient had severe weight loss during induction of chemotherapy. His body weight on admission was $27 \mathrm{~kg}$, during induction his body weight was 22 $\mathrm{kg}$, he lost about $5 \mathrm{~kg}$ during induction. During induction, he was complaining from severe gastroenteritis with high grade fever and severe oral mucositis which lead to decrease oral intake and lead to weight loss. While in the study by Rajesh et al. show that 9 cases have demonstrated loss of weight during induction range from $(0.2-5.8 \mathrm{~kg})$. These patients had complicated course during induction of chemotherapy such as (gastroenteritis, severe oral mucosities, bleeding, febrile neutropenia, pneumonia and sepsis) which can lead to decrease oral intake and severe weight loss during induction [17].

In this study, there is increase in mid upper arm circumference during induction by $(0.3 \mathrm{~cm})$ than before induction, although statistically not significant.

A study by Delbecque et al. also found no significant change in MUAC during induction [18], this may be due to large amount of protein in diet. There was a significant increase in body mass index during induction, this due to same effect of steroid on body weight. In this study, there was no change in all body parameters in comparison between during and after induction by 6 weeks. This may be due to short duration post induction. Also, Delbecque et al. documented no change in body composition during and after induction [18]. The most presenting feature of children in this study at time of presentation was pallor, comprising 14 (46.6\%) of the total patients with mean $\mathrm{Hb}$ of $(6.5 \mathrm{~g} / \mathrm{dl})$. Induction of chemotherapy was not started unless stabilization of general condition of the patients by supportive measure such as blood transfusion, platlate transfusion, treatment of infection, it is expected that $\mathrm{Hb}$ increases during induction. Similar result was obtained by Carriottee et al. [13]. Serum calcium was significantly decrease during induction. This is in agreement with a study by Chariotte [13] et al. The explanation for this decrease due to effect of drug during induction such as steroid (predinsolone induce calcium loss), antibiotics, prolonged immobilization also induce calcium loss. In tumor lyses syndrome, there is hypercalciuria and loss of calcium in the urine result in hypocalcaemia [13].

The use of steroid and nephrotoxic agent may worsen hypercalciuria putting the patient at high risk of osteopenia and fractures [1].

In this study, there was significant decrease in total serum protein and serum albumin during induction.

Similar result was obtained by Charriotte et al. The explanation for that decrease due to effect of drugs that used during induction such as $\mathrm{L}$ - Asparginase induce hypoproteinemia, steroid induce protein muscle loss, antibiotics decrease protein synthesis [13].

Albumin concentration decreases in acutely or chronically ill patients because of the effects of inflammatory mediators on hepatic protein synthesis. Severe liver and renal disease, 
intravascular volume overload and zinc deficiency decrease serum albumin levels [19]. In cancer patients, there is derangement of macronutrient metabolism such as the presence of protein catabolism, hypoalbuminemia is common. An increase in muscle protein breakdown and decrease skeletal muscle protein synthesis seems to be of primary importance. A net loss of skeletal muscle protein is a common finding with malignancy and is particularly problematic in the growing child. Furthermore, there is disturbance of whole protein homeostasis with net catabolism, negative nitrogen balance, increase in blood urea nitrogen, and fall in serum albumin [1].

There is clinical impression that cancer patients especially when undergoing chemotherapy, ingest lower amount of nutrient than age based standard, these dietary changes therefore place them at risk of negative energy balance [1].

Another important reason for decreased nutrient intake is anorexia and other gastrointestinal side effects of chemotherapy. Mucosal damage is generally dose related, with increased risk of mucosal toxicity with high dose induction therapy, escalating dose pattern and combination chemotherapy treatment [1].

High dose chemotherapy often produce painful mucositis that can reduce nutritional intake for days to weeks. Other gastrointestinal side effects of cancer treatment include esophagitis, enteritis with malabsorption and diarrhea. Taste perception has also shown to be altered in cancer patients receiving chemotherapy, with an increasing sensitivity to bitter taste; this phenomenon may lead to decrease food intake, and may make the use of oral supplement difficult [1]. In this study, there is a significant decrease in serum cholesterol during induction than before induction. Nutrition can significantly improve or worsen a person's lipid profile. A diet high in saturated fat and can increase total cholesterol level. Plant based diet high in fiber and unsaturated fatty acids can lower total cholesterol level [19].

During induction of chemotherapy there is decrease nutrient intake by the patients due to causes that mention above such as anorexia, gastrointestinal side effect of chemotherapy (oral mucositis, gastroenteritis, and malabsorption [19].

Other study shows increase serum cholesterol during induction due to effect of drug such as L-Asparginase induce hypertriglyceridemia [1].

Treatment with chemotherapy is associated with decrease fat utilization in children newly diagnosed with ALL [1]

In cases of protein energy malnutrition, patients experience an increase in plasma total triacylglycerol concentration, a measure of fat stored in the body and decreased high density lipoprotein concentration. This caused by reduction in the activity of lipoprotein lipase [20].

According to random blood sugar, in this study there is increase in blood sugar during induction with no significant $P$ value. In cancer patients who are malnourished, increase glucose production occurs and there are abnormalities with insulin secretion and action. Malnutrition can cause glucose intolerance and impairment of insulin secretion [1,12]. However, insulin resistance caused by disease or medication used during treatment, including glucocorticiods and LAsparginase is more common [21,22]. When hyperglycemia occurs, synthesis of very low density lipoprotein is driven up, and both triglyceride and cholesterol level rise (19). According to changes in hematological and biochemical data during and after induction, there is no significant change in any one of these data. In this study, there is no significant association exists between body measurement and hematological and biochemical data in relation to sex, ALL risk group, ALL morphological subtypes.

\section{Conclusion}

Malnutrition exists in a significant proportion of children with acute lymphoblastic leukemia so adequate nutrition is an important in such children, to ensure optimal treatment.

\section{References}

1. Bechard LJ, Adiv OE, Jaksic T, Duggan C (2006) Nutritional supportive care. In: Pizzo PA, Poplack DG (eds). Principles and practice of pediatric oncology. (5thedn). Philadelphia, Lippincott William and Wilkins 1330-1338.

2. Sgarberie UR, Fisberg M, Tone LG (2006) Nutritional assessment and serum zinc and copper concentration among children with acute lymphocytic leukemia: a longitudinal study. Sao Paulo Med J 124: 316-320.

3. Cornelio U, Attilio R, Massimo B, Anna B, Simona S, et al. (1996) Nutritional status in untreated children with acute leukemia as compared with children without malignancy. Journal of Pediatric Gastroenterology Nutrition 23: 34-37.

4. Muller A, Zurcher G (2008) Malnutrition in cancer patients. In: Berger DP, Engelhardt M, Hen BH, Mertelsmann B (eds). Concise Manual of Hematology and Oncology 225.

5. Holmes S (2002) Nutrition and cancer. Cancer Nursing Practice 1: $31-38$.

6. ladas EJ, Sacks N, Meacham L, Henry D, Enriguez L, et al. (2005) A multidisciplinary review of nutritional considerations in the pediatric oncology population. Nutr Clin pract 20: 377-393.

7. Phillips SM, Jensen G, Motil KJ, Hoppin GA (2010) Indication for nutritional assessment in childhood. 25: 379.

8. http://www.uptodate.com/contents/indications-for-nutritionalassessment-in-childhood

9. Mosby TT, Barr RD, Pencharz PB (2009) Nutritional assessment of children with cancer. J Pediatr Oncol Nurs. 26: 179-186.

10. Yaris N, Akyus C, Coskun T, Kutluk T, Buyukpamukcu M (2002) Nutritional status of children with cancer and its effect on survival. Turk J Pediater. 44: 35.

11. Zalina AZ, Shahar S, Jamal RA, Aini N (2009) Assessing the nutritional status of children with leukemia from hospitals in Kuala Lumpur. Malaysia Journal Nutrition 15: 45- 51.

12. Keane V (2007) Assessment of Growth. In: Kliegman RM, Behrman RE, Jenson HB, Stanton BF (eds) Nelson Text Book of Pediatrics (18thedn) 71-73. 
13. Charriotte GN, Derrick BJ, Alfred JZ (1982) Nutritional assessment of the child with cancer. Cancer Research (Suppl) Los Angeles, California: UCLA school of public health and medicine 42: 699-712.

14. Pesce MA (2007) Laboratory testing in infants and children. In: Kliegman RM, Behrman RE, Jenson HB, Stanton BF (eds) Nelson Text Book of Pediatrics (18thedn) 2: 2945-2949.

15. National cholesterol Education Program (NCEP) (1992) NCEP Expert Panel on blood cholesterol levels in children and adolescent. Highlight of the report. Pediatrics 89-495.

16. Yu LC, Kuvibidila S, Ducos R, Warrier RP (1997) Nutritional status of children with leukemia. Med Pediatr Oncol 28: 321-322.

17. Kumar R, Marwaha RK, Bhalla AK, Gulati M (2000) Protein energy malnutrition and skeletal muscle wasting in childhood ALL. Indian pediatric 73: 720- 726.

18. Delbecque-Boussared L, Frederia G, Simon A, Brigitte N, Francoise $\mathrm{M}$, et al. (1997) Nutritional status of children with ALL: A longitudinal study. AM J Clin Nutr 65: 95-100.
19. Tamminga RY, Kamps WA, Drager NM, Himphery GB (1992) Longitudinal anthropometric study in children with ALL. Acta Pediater Scand 8: 61-65.

20. Mosby TT, Barr RD, Pencharz PB (2009) Nutritional assessment of children with cancer. J Pediatr Oncol Nurs 26: 179-186.

21. Vlassara H, Spiegel RJ, Doval DS, Cerami A (1986) Reduced plasma lipo-protein lipase activity in patients with malignancy associated weight loss. Hormone and Metabolic Research 18: 698-703.

22. Robertson JR, Sparker HL, Shelso J, Zhou Y, Mtzker ML, et al. (2008) Clinical consequences of hyperglycemia during remission induction therapy for pediatric acute lymphoblastic leukemia. Leukemia 23: 245-250. 